\title{
Analisis Kemampuan Bahasa pada Anak Usia Dini
melalui Penggunaan Media Audio Visual
}

\author{
Resha Aftika Dewi' ${ }^{1}$, Delfi Eliza ${ }^{2}$ \\ ${ }^{1}$ Magister Pendidikan Anak Usia Dini, Universitas Negeri Padang \\ ${ }^{2}$ Dosen Pendidikan Anak Usia Dini, Universitas Negeri Padang \\ E-mail: reshaaftika09@gmail.com, deliza.zarni@gmail.com
}

\begin{tabular}{|c|c|}
\hline Article Info & Abstract \\
\hline Article History & This research was conducted to determine the analysis of language skills in early \\
\hline Received: 2021-11-10 & childhood through the use of audio-visual media. This research is a qualitative research \\
\hline Revised: 2021-11-28 & with a literature study research method which aims to determine how the \\
\hline & development of language skills in early childhood using audio-visual media. In this \\
\hline & literature study research, the data used are secondary data, where in this study, it \\
\hline Keywords: & collects sources from books, journals, scientific articles and reviews of previous articles \\
\hline Language Skills; & related to the concepts discussed. This study focuses on children's language skills. This \\
\hline & is an important part of analyzing language skills in children which will have an impact \\
\hline Visual Media. & $\begin{array}{l}\text { on the subsequent development of the child. The results of this study indicate that } \\
\text { language skills in early childhood are very important to be developed from an early } \\
\text { age, because children who have good language skills will have an effect on children's } \\
\text { daily life. By using audio-visual media is one way that an educator can improve }\end{array}$ \\
\hline
\end{tabular}

Artikel Info
Sejarah Artikel
Diterima: $2021-11-10$
Direvisi: $2021-11-28$
Dipublikasi: $2021-12-06$

Kata kunci:

Kemampuan Bahasa;

Anak Usia Dini;

Media;

Audio Visual.

\begin{abstract}
Abstrak
Penelitian ini dilakukan untuk mengetahui dalam menganalisis kemampuan bahasa pada anak usia dini melalui penggunaan media audio visual. Penelitian ini merupakan penelitian kualitatif dengan metode peneltian studi literature yang memiliki tujuan untuk mengetahui bagaimana perkembangan kemampuan bahasa pada anak usia dini dengan penggunaan media audio visual. Dalam peneltian studi literatur ini data yang digunakan yaitu data sekunder dimana dalam penelitian ini mengumpulkan sumber dari buku, jurnal, artikel ilmiah serta review artikel terdahulu yang berkaitan dengan konsep yang dibahas. Penelitian ini berfokus tentang kemampuan bahasa anak. Hal ini menjadi bagian penting dalam menganalisis tentang kemampuan bahasa pada anak yang akan berdampak pada perkembangan anak selanjutnya. Hasil penelitian ini menunjukkan bahwa kemampua bahasa pada anak usia dini sangat penting di kembangkan sejak dini, karena anak yang memiliki kemampuan bahasanya baik akan berpengaruh pada kehidupan sehari-hari anak. Dengan menggunakan media audio visual adalah salah satu cara yang dapat digunakan seorang pendidik dalam meningkatkan kemampuan bahasa dan dapat membuat anak akan lebih tertarik dalam belajar.
\end{abstract}

\section{PENDAHULUAN}

Pendidikan Anak Usia Dini (PAUD) memiliki tujuan dalam aspek perkembangan anak usia 0 sampai 8 tahun. Anak usia dini juga disebut dengan masa golden age dimana anak sedang berada pada masa perkembangan yang suka meniru dan lebih cepat menerima rangsangan yang diberikan. Sama halnya yang di ungkapkan oleh Bredekamp \& Copple dalam Suryana (2014) bahwa pada pendidikan anak usia dini merupakan sebagai pelayanan pendidikan untuk anak sejak lahir hingga usia delapan tahun, salah satu pendidikan anak usia dini yang diberikan kepada anak yaitu pendidikan Taman Kanakkanak. Adapun program maupun materi pembelajaran yang diberikan kepada anak harus diterapkan secara saintifik yang berlandaskan kepada prinsip pendidikan anak usia dini. Disamping itu dalam metode pembelajaran, pendekatan, model pembelajaran, hingga media pembelajaran yang digunakan hendak mempertimbangkan norma dan nilai-nilai kehidupan anak usia dini (Suryana, 2019). Anak usia dini memiliki kecerdasan yang berbeda setiap individu. Maka dari itu ada proses belajar di Taman Kanak-kanak memiliki peran penting dalam menumbuhkembangkan aspek perkembangan yang dimiliki oleh anak dengan maksimal. Setiap anak memiliki potensi perkembangan yang berbeda dalam kelebihan aspek tertentu anak juga memiliki kekurangan dalam aspek yang lain. Dalam proses pembelajaran yang 
diberikan secara optimal dapat menjadikan anak yang memiliki potensi lebih baik di lingkungannya (Rahmalia \& Suryana, 2021).

Anak usia dini sangat membutuhkan pemberian rangsangan dan juga perlu diberikan banyak pengetahuan serta pengalaman yang dapat memberikan anak memiliki pengetahuan dan pengalaman yang baru. Aspek perkembangan anak yang harus di tingkatkan, aspek perkembangan anak yang dimaksud yaitu nilai agama dan moral, sosial emosinal, fisik motorik, kognitif, bahasa dan seni. Suryana \& Mahyudin (2014) pendidikan anak usia dini yang diberikan kepada anak usia dini diharapkan sangat membantu dalam menstimulus perkembangan pada anak, karena disebutkan bahwa pada sejak usia dini lah anak mengalami potensi perkembangan dengan cepat. Anak usia dini merupakan periode awal yang penting dan sangat berpengaruh terhadap pertumbuhan dan perkembangan selanjutnya.

Salah satu aspek yang harus di tingkatkan pada anak yaitu kemampuan bahasa pada anak. Perkembangan bahasa anak pada Tahun-tahun awal adalah salah satu faktornya mempengaruhi perkembangan kognitif anak. Semakin lama anak itu, Kembangkan dan mulailah untuk bisa Kemudian pahami lingkungan Perkembangan bahasa juga meningkat Dikembangkan dari level sederhana Ke level yang paling kompleks. Bahasa merupakan alat atau sarana untuk berkomunikasi antar sesama, maka dari itu kemampuan bahasa sangat berperan penting dalam diri manusia terutama pada anak, maka dari itu kemampuan bahasa pada anak sangat penting dikembangkan sejak dini. Kemampuan bahasa yang dimiliki seseorang akan terus berkembang sesuai dengan tahap perkembangannya. Sebagaimana yang telah diungkapkan oleh Susanto (dalam Nurlaeni \& Juniarti, 2017) bahwa bahasa ialah alat yang digunakan untuk berpikir dalam mengekspresikan diri serta alat untuk bersosialisasi. Keterampilan bahasa juga termasuk hal yang penting dalam rangka pembentukan konsep, informasi, dan pemecahan masalah, dengan menggunakan bahasa juga mampu memahami komunikasi dalam pikiran serta perasaan.

Menurut Sari, Suryana \& Pransiska (2018) bahwa dalam belajar bahasa pada anak usia dini dimulai dari mengenalkan berkomunikasi dengan baik serta dalam mengenal simbol huruf. Mengajarkan anak dengan kemampuan bahasa ini mampu memberikan anak tahu cara berkomunikasi dengan baik serta anak mampu mengutarakan perasaannya. Mengingat pentingnya mengembangkan kemampuan bahasa sejak usia dini maka perlunya pendidikan yang mampu menstimulus kemampuan bahasa anak dengan baik. Peran lingkungan sangat dibutuhkan oleh anak, lingkungan keluarga serta lingkungan sekolah haruslah mampu bekerjasama dalam ikut serta meningkatkan kemampuan bahasa anak.

Dalam meningkatkan kemampuan bahasa dibutuhkan media pembelajaran yang membantu dalam menstimulus proses mengembangkan kemampuan bahasa pada anak yaitu menggunakan media audio visual. Menurut Hamdani (dalam Limarga, 2017) bahwa Media audio visual yaitu kombinasi audio dan visual atau dapat disebut dangan media pandang dan dengar. Dengan menggunakan media audio visual mampu membuat anak termotivasi dan lebih tertarik dalam belajar serta lebih mudah anak dalam memahami isi pembelajarannya. Oleh karena itu peneliti ingin menganalisis tentang kemampuan bahasa pada anak usia dini melalui penggunaan media audio visual.

\section{METODE PENELITIAN}

Penelitian ini menggunakan penelitian kualitatif dengan metode penelitian studi literatur dimana dalam penelitian ini mengkaji tentang gambaran-gambaran yang ada, yang sedang berlangsung saat ini atau saat yang masa lampau. Penelitian ini dilakukan dengan menggabungkan hasil penelitian kemampuan bahasa pada anak usia dini serta penggunaan media audio visual. Penelitian studi literatur ini mengikuti langkah yaitu dimulai dari mengumpulkan data pustaka, membaca, dan mencatat, serta membandingkan literature kemudian di olah dan dapat disimpulkan, data dalam penelitian ini juga menggunakan data sekunder yaitu yang berasal dari buku, jurnal, artikel ilmiah, serta review yang berisikan tentang konsep yang diteliti.

\section{HASIL DAN PEMBAHASAN}

\section{A. Hasil Penelitian}

Dalam penelitian ini dengan judul analisis kemampuan bahasa pada anak usia dini melalui penggunaan media audio visual, sebelumnya juga sudah ada penelitian yang serupa. Dari penelitian Cahyati (2018) ditemukan hasil penelitiannya yaitu terdapat bahwa hasil pengaruh yang signifikan dengan menggunakan video pembelajaran terhadap meningkatkan karakter tanggung jawab pada anak TK B. Selanjutnya dilihat dari penelitian tentang kemampuan bahasa pada anak usia 
dini dari hasil penelitian Pebriana (2017) bahwa kemampuan bahasa yaitu dalam kemampuan menyimak, berbicara, membaca, dan menulis merupakan aspek yang sangat penting digunakan dalam sarana komunikasi. Hal ini dibuktikan dalam penelitiannya bahwa keempat aspek tersebut dapat ditingkatkan dengan metode bercerita dan dongeng.

Adapun penelitian dari Setyawan (2016) bahwa berdasarkan penelitian tindakan kelas yang dilakukan pada peserta didik kelas A PAUD Nawakartika Desa Beran Kecamatan Ngawi Kabupaten Ngawi, dapat disimpulkan bahwa kemampuan bahasa pada anak dapat ditingkatkan melalui media audio visual berbasis android. Terdapat pula penelitian dari Mekarningsih dkk (2015) yaitu dalam peningkatan kemampuan berbahasa secara lisan pada anak dapat dilakukan dengan menggunakan metode bercerita dengan bantuan media audio visual.

Dari beberapa hasil penelitian yang di peroleh dari penelitian sebelumnya didapatkan bahwa dalam menganalisis kemampuan bahasa pada anak usia dini dengan menggunakan media audio visual dapat dikatakan bahwa media audio visual merupakan salah satu cara yang dapat digunakan dalam pendidikan anak usia dini dalam proses belajar yang dapat menarik anak dan membangkitkan minat anak dalam belajar. Dalam penelitian sebelumnya aspek perkembangan anak usia dini yaitu kemampuan bahasa yang ada pada anak dapat di stimulasikan dengan berbagai cara terutama yaitu dengan menggunakan media audio visual.

\section{B. Pembahasan}

Pendidikan anak usia dini ialah sarana untuk meningkatkan perkembangan yang dibutuhkan oleh anak usia dini dalam aspek perkembangannya yaitu kogintif, sosial emosi-onal, nilai nilai agama dan moral, bahasa serta fisik motorik (Mursid, 2017). Suryana (2018) mengungkapkan bahwa hasil akhir dari pendidikan yang diberikan yaitu memulangkan anak usia dini yang sebagai subjek sasaran pendidikan, yang dikatakan pendidikan berhasil yaitu pendidikan yang mampu memberikan subjek menjadikan seperti dirinya, pembelajaran yang dilakukan di PAUD memiliki tujuan untuk mengenalkan kegiatan-kegiatan anak yang dibentuk individu, kelompok kecil maupun kelompok besar. Pendidik hanya bertugas memberikan peluang kepada anak untuk memberikan gagasan serta memberikan dorongan kepada anak agar lebih terbangun pengalaman serta pengetahuan yang dimiliki oleh anak pada saat pembelajaran (Dewi \& Suryana, 2020).

Salah satu aspek perkembangan yang perlu ditingkatkan sejak usia dini yaitu pada perkembangan bahasa pada anak. Dhieni dalam (Setyawan, 2016) mengungkapkan bahwa dalam perkembangan bahsa pada anak tidak bias berkembang begitu saja tanpa diberikan stimulus dari lingkungan sekitarnya. Anak yang memiliki perkembangan kemampuan bahasa dengan baik mampu bersosialisasi dengan lingkungannya dengan benar, menurut Jazuly (Alam \& Lestari, 2020) mengatakan bahwa sejak usia dini dalam kemampuan bahasanya memiliki tingkat kemudahan untuk menerima serta memahami apa yang diberikan dengan pengetahuan yang baru dengan logika yang dimiliki oleh anak. Hal ini dikarenakan anak memiliki karakteristik yang unik yaitu pada kemampuan anak suka meniru sehingga apa yang dilihat dan yang diucapkan oleh lingkungan sekitar anak akan mengamati dengan baik apa yang diucapkan tersebut.

Menurut Rahmadani, dkk (2019) bahwa dalam mengembangkan kemampuan bahasa pada anak termasuk hal yang sangat penting dalam pendidikan prasekolah. Salah satunya kemampuan membaca dan menulis dalam kemampuan bahasa yang perlu dikembangkan dan yang harus dikuasi oleh anak, karena pentingnya pembelajaran dalam mengembangkan kemampuan bahasa pada anak maka pengenalan huruf adalah pembelajaran yang tepat dilakukan pada usia 4-5 tahun. Dalam mengenalkan huruf pendidik haruslah memberikan kegiatan yang sesuai dengan tingkat perkembangan pada anak.

Tingkatan kemampuan dan keterampilan anak sesuai dengan tahapannya Perkembangannya menunjukkan bahwa tahap perkembangan anak sedang terungkap melalui pemikirannya dan penggunaan kata-katanya telah meningkat. Dapat disimpulkan bahwa perkembangan bahasa anak dimulai pada masa bayi, yaitu tergantung pada pengalaman bahasa, kemahiran dan kemajuan. Perkembangan dari Bahasa merupakan sarana komunikasi sosial yang efektif bagi anak. Dengan berkembangnya bahasa anak, makan akan memudahkan anak untuk berekspresi Apa yang mereka inginkan dan butuhkan. Oleh karena itu, bahasa dikembangkan untuk 
tujuan anak usia dini adalah agar anak dapat berkomunikasi dengan baik. Sebagaimana yang diungkapkan oleh Amelin dkk dalam (Winarti \& Suryana, 2020) bahwa bahasa adalah salah satu sarana yang paling penting dalam individu manusia, menggunakan bahasa seseorang lebih mudah menyampaikan serta mengutarakan pesan kepada individu lainnya baik dalam tulisan, lisan serta hanya dalam bentuk syimbol tertentu.

Meningkatkan kemampuan bahasa pada anak usia dini dengan menggunakan media pembelajaran adalah solusi terbaik yang dapat dilakukan. Menurut Heinic dkk dalam (Zaman dkk, 2008) menyebutkan bahwa media adalah saluran komunikasi. Media yang artinya perantara sumber pesan dari bahasa latin yaitu medium dan juga penerima pesan. Adapun hal sama yang diungkapkan oleh Khadijah (2016) Media merupakan salah satu yang bisa digunakan dalam menyalurkan atau mengirimkan pesan kepada yang menerima pesan sehingga dapat membentuk pikiran, perasaan, perhatian, minat serta perhatian kepada anak sehingga dapat membentuk kegiatan pembelajaran.

Media pembelajaran sebagai salah satu peranan penting untuk proses pembelajaran. Penggunaan media dalam proses belajar memberikan manfaat serta dampak positif sehingga pembelajaran berjalan dengan kondusif, serta adanya umpan balik dalam proses belajar mengajar yang akan memberikan pembelajaran yang optimal. Selanjutnya Dageng dalam (Guslinda \& Kurnia, 2018) mengungkapkan bahwa media pembelajaran merupakan sebagai alat komponen dalam menyampaikan pesan yang akan disampaikan.

Menurut Levie \& Lentz dalam (Guslinda \& Kurnia, 2018) adapun fungsi dalam media pembelajaran dapat menarik perhatian anak dalam proses belajar, dapat membantu anak dalam mengingat pembelajaran lebih kuat dengan adanya media yang bergambar. Selanjutnya menurut Hamalik (2005) mengungkapkan manfaat media pembelajaran yaitu menjadikan peran guru yang positif dan produktif, mampu meningkatkan kualitas pembelajaran, serta dapat membuat suasana pembelajaran lebih menarik, demikian dapat disimpulkan dari beberapa pendapat tentang media Pembelajaran merupakan salah satu bentuk alat, metode atau teknologi digunakan untuk memandu pesan, membantu memperkuat materi pembelajaran, dan dengan demikian membangkitkan minat serta motivasi siswa atau siswa untuk mengikuti proses tersebut belajar dan mengajar. Dalam hal ini, penerima pesan adalah siswa, yang terbaik adalah tidak terpisahkan dalam setiap studi gunakan media. Media pembelajaran sebenarnya adalah alat ini sangat berguna bagi para pendidik untuk membantu pekerjaan pendidikan mereka. Secara umum, media pembelajaran bermanfaat membimbing dan membimbing siswa untuk mendapatkan pengalaman belajar Itu tergantung pada interaksi siswa dengan media. Menggunakan media pembelajaran dengan cara-cara berikut tentunya tujuan pembelajaran akan meningkatkan hasil belajar. adapun media pembelajaran yang cocok dalam meningkatkan kemampuan bahasa pada anak usia dini yaitu media audio visual.

Media audio visual merupakan media yang lebih menarik dibanding dengan media lainnya, karena dalam media audio visual ini dapat menggabungkan pendengaran serta penglihatan sekaligus. Media ini dapat digolongkan yaitu video, film, serta benda yang lain bisa didengar dan dilihat (Fadillah, 2017). Sama halnya yang diungkapkan oleh Wina Sanjaya dalam (Hartati, 2019) bahwa media audio visual adalah media yang mengandung suara serta dapat dilihat dengan adanya gambar, contohnya rekaman video, berbagai film yang sesuai dengan anak, suara, dan lainnya. Secara langsung dengan menggunakan media dapat memberikan anak sengan suasana segar, menarik perhatian anak serta memberikan anak pengalaman yang baru.

Beberapa pendapat tersebut dapat disimpulkan bahwa media audio visual merupakan media yang lebih menarik untuk diterapkan pada anak serta mudah bagi guru dalam penerapannya. Media audio visual ini terdiri suara, gambar serta video yang dapat di dengar dan dilihat oleh anak hingga dapat membuat proses pembelajaran lebih kondusif. Media dapat meningkatkan kemampuan bahasa pada anak usia dini.

\section{SIMPULAN DAN SARAN}

\section{A. Simpulan}

Kemampuan bahasa pada anak usia dini merupakan salah satu aspek perkembangan pada anak usia dini yang harus ditingkatkan. Anak yang memiliki perkembangan bahasa sangat berpengaruh untuk anak dalam 
menuju ke perkembangan selanjutnya, karena dengan perkembangan bahasa anak mampu menggunakan bahasa secara lisan maupun tulisan dengan baik dalam bersosialisasi serta berinteraksi denga lingkungan. Dengan menggunakan media audio visual dapat mempengaruhi anak akan lebih tertarik dalam belajar, dengan menggunakan audio visual sebagai alat pembelajaran, anak akan lebih tertarik serta mudah dalam memahami pembelajarannya.

\section{B. Saran}

Disarankan Untuk peneliti lain dalam melakukan penelitian yang sama dapat mengembangkan media audio visual untuk meningkatkan kemampuan bahasa pada anak usia dini sehingga dapat di terapkan di Taman Kanak-kanak

\section{DAFTAR RUJUKAN}

Alam, Syah Khalif \& Lestari, Ririn Hunafa. (2020). Pengembangan Kemampuan Bahasa Reseptif Anak Usia Dini dalam Memperkenalkan Bahasa Inggris Melalui Flash Card. Jurnal Obsesi : Jurnal Pendidikan Anak Usia Dini. Volume 4 (1). Hal 274-279

Cahyati, Nika. (2018). Penggunaan Media Audio Visual Terhadao Karakter Tanggung Jawab Anak Usia 5-6 Tahun. Jurnal: Golden Age Hamzanwadi University. Volume 2 (2). Hal 75-84.

Dewi, Iratna. \& Suryana, Dadan. (2020). Analisis Evaluasi Kinerja Pendidik Paud di PAUD Al Azhar Bukittinggi. Jurnal Obsesi: Jurnal Pendidikan Anak Usia Dini. Vol 4 (2). Hal 1051-1059

Fadillah. (2017). Bermain \& Permainan Anak Usia Dini. Jakarta: KENCANA

Guslinda. \& Kurnia, Rita. (2018). Media Pembelajaran Anak Usia Dini. Surabaya: CV. Jakad Publishing Surabaya

Hamalik. (2005). Keterampilan Dasar Mengajar. Malang: Fakultas Tarbiyah.

Hartati, Sri. (2019). Pengaruh Media Audio Visual Terhadap Stimulasi Sensori Pendengaran Bagi Anak Toddler di TPA/PAUD. Jurnal: Early Childhood Education Journal of Indonesia. Volume 2 (1). Hal 1-5
Khadijah, 2016. Pengembangan Kognitif Anak Usia Dini. Medan: Perdana Publishing.

Limarga, Debora Meiliana. (2017). Penerapan Metode Bercerita dengan Media Audio Visual untuk Meningkatkan Kemampuan Empati Anak Usia Dini. Jurnal : Tunas Siliwangi. $\quad$ Volume 3 (1). Hal 86-104

Mursid. (2017). Pengembangan Pembelajaran PAUD. Bandung: PT REMAJA ROSDAKARYA.

Nurlaeni. \& Juniarti. (2017). Peran Orang Tua dalam Mengembangkan Kemampuan Bahasa Pada Anak Usia 4-6 Tahun. Jurnal: Pelita PAUD.

Pebriana, Putri Hana. (2017). Analisis Kemampuan Berbahasa dan Penanaman Moral pada Anak Usia Dini melalui Metode Mendongeng. Jurnal: Jurnal Obsesi. Vol 1 (2). Hal 139-147.

Rahmadani, Fita. Suryana, Dadan. \& Hartati, Sri. (2019). Pengaruh Media Sandpapaer Letter Terhadap Kemampuan Mengenal Huruf Anak di TK Islam Budi Mulia Padang. Jurnal Ilmiah Pesona PAUD. Vol. 6 (1). Hal 56-67

Rahmalia, Denny \& Suryana, Dadan. (2021). Pengembangan Media Papan Flanel untuk Meningkatkan Kecerdasan Logika Matematikan pada Anak. Jurnal Basicedu. Vol 5 (2). Hal 605-618

Sari, Cici Ratna. Suryana, Dadan \& Pransiska, Rismareni. (2018). Keterlambatan Bicara Anak Usia 5 Tahun. Prosiding Seminar dan Diskusi Nasional Pendidikan Dasar. ISSN: 2528-5564

Setyawan, Farid Helmi. (2016). Meningkatkan Kemampuan Berbahasa Anak Usia Dini Melalui Model Pembelajaran Audio Visual Berbasis Android. Jurnal PG PAUD. Volume 3 (2). Hal 1-75

Suryana \& Novi. (2019). Thematic Pop-Up Book based of Learning Media Early Childhood Language Development. Jurnal Pendidikan Usia Dini Volume 13 (1). Hal 43-57

Suryana, Dadan \& Mahyudin, Nenny. (2014). Dasar-Dasar Pendidikan TK. Tanggerang Selatan: Universitas Terbuka 
Suryana, Dadan. (2014). Kurikulum Pendidikan Anak Usia Dini Berbasis Perkembangan Anak. Jurnal: PESONA DASAR. Volume 1 (3). Hal 65-72

Suryana, Dadan. (2018). Pendidikan Anak Usia Dini Stimulasi dan Aspek Perkembangan Anak. Jakarta: PRENANDA GROUP
Winarti, Winarti \& Suryana, Dadan. (2020). Pengaruh Permainan Duppet Fun terhadap Kemampuan Membaca Anak Usia Dini. Jurnal Obsesi: Jurnal Pendidikan Anak Usia Dini. Volume 4 (2). Hal 873-882

Zaman, Badru., Hernawan, Asep Hery., \& Eliyawati, Cucu. (2008). Media dan Sumber Belajar TK. Jakarta: Penerbit Universitas Terbuka 